\title{
Association between leptin combined genotypes and milk performance traits of Polish Black-and-White cows*
}

\begin{abstract}
The aim of this study was to estimate the relations between the leptin combined genotypes versus milk performance traits (yields of milk, protein, and fat, as well as protein and fat content). The investigation was performed on 860 Black-and-White cows with a different share of the of Holstein-Friesian genes, kept in Pomerania. Frequencies of the LEP-C3100T/Sau3AI genotypes were: CC/AA - 0. 315, CT/AA - 0.272 and $\mathrm{CC} / \mathrm{AB}-0.142$. The frequencies of the remaining genotypes did not exceed 0.100 . Statistically significant $(\mathrm{P} \leq 0.01)$ relation between the leptin combined genotypes (LEP-C3100T/Sau3AI) and milk, protein, and fat yield were observed. These traits were significantly higher in the CC/BB genotype cows.
\end{abstract}

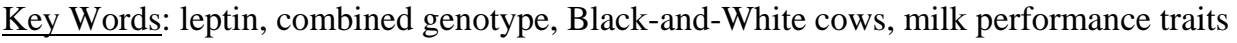

\section{Zusammenfassung}

Titel der Arbeit: Zusammenhang zwischen kombinierten Leptingenotypen und Milchleistungsmerkmalen bei Polnischen Schwarzbunten Kühen

Das Ziel der Untersuchungen war die Bestimmung der Assoziation zwischen den kombinierten Leptingenotypen und Milchleistungsmerkmalen (Milch-, Protein- und Fettleistung, sowie Protein- und Fettgehalt). Die Untersuchungen wurden an 860 Schwarzbunten Kühen mit unterschiedlichem Holstein-Friesian Genanteil aus Pommern durchgeführt. Die Frequenzen der Genotypen LEP-C3100T/Sau3AI betrugen: CC/AA - 0.315, CT/AA - 0.272, und CC/AB - 0.142. Die Frequenzen aller übrigen Genotypen waren niedriger als 0,100. Es wurde eine statisch relevante Assoziation $(\mathrm{P} \leq 0.01)$ zwischen den kombinierten Leptingenotypen (LEPC3100T/Sau3AI) und Milch-, Protein- sowie Fettleistung festgestellt. Die Werte dieser Eigenschaften waren mit statistischer Relevanz höher bei Kühen mit den Genotypen CC/BB.

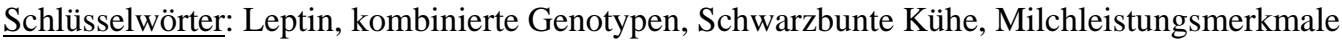

\section{Introduction}

In view of the reduction in the stock of dairy cattle in Poland, observed in the recent years, cattle breeders - in their efforts to meet the market demand - tend to select for the cattle of increased milk yield and improved milk quality. Therefore efforts are taken to identify quantitative trait loci (QTLs) or QTL-linked genes (genetic markers) which may contribute to a further and much faster improvement in those traits. The progress in molecular techniques makes it possible to rapidly and efficiently identify the desired genotypes.

A comprehensive research into associations between QTLs or genetic markers and milk performance traits is in progress (GRAML and PIRCHNER, 2003). Attention is being focused primarily on two groups of traits: milk, protein, and fat yields (kg) and milk protein and fat contents (\%). Initial reports on relation between certain genetic variants of leptin and milk performance traits of cattle have been recently published.

Leptin is a $16 \mathrm{kDA}$ polypeptide hormone produced primarily by adipose tissue (HALAAS et al., 1995; ZHANG et al., 1994). Numerous studies demonstrated leptin

\footnotetext{
* This work was supported by Agricultural Academy of Szczecin; BW/DB/13/99
} 
to affect a number of processes in the body. The hormone is involved in the energy balance by controlling food intake and energy expenditure (BRUNNER et al., 1997). It also participates in glucose and lipid metabolism (HOUSEKNECHT and PORTOCARRERO, 1998). It is also known to be involved in functioning of the endocrine system (CONSIDINE, 1997; XIE at al., 1999), reproduction (BARASH et al., 1996), and immune system (LORD et al., 1998).

The white adipose tissue is the major site of the leptin gene expression and leptin synthesis (JI et al., 1998; ZHANG et al., 1994). Lower amounts of leptin are also synthesised in the mammary gland during lactation (BONNET et al., 2002), in the placenta (GONG et al., 1996), and in the stomach (BADO et al., 1998). Tissue leptin concentration and leptin gene expression are closely related to the amount of adipose tissue (DELAVAUD et al., 2002). Important is also nutrition (DELAVAUD et al., 2002; TSUCHIYA et al., 1998) as well as hormones (BRANN et al., 1999; SALADIN et al., 1995). Leptin, produced by the mammary gland, is secreted to milk. The presence of leptin was detected in colostrum and/or milk of cattle (BONNET et al., 2002).

The gene encoding leptin was mapped to bovine chromosome 4 (STONE et al., 1996) and it is considered as a candidate gene for milk performance related traits in cattle. QTLs for milk performance on bovine chromosome 4, close to the leptin gene, were described (LINDERSSON et al., 1998). There were numerous polymorphic sites within the leptin gene. However, research on associations between leptin gene polymorphism and performance traits in dairy cattle is rather scant (BUCHANAN et al., 2003; LIEFERS et al., 2002, ZWIERZCHOWSKI et al., 2002), while literature data on associations between leptin combined genotypes and those traits are absent.

The need to further improve the milk performance traits in cattle as well as the analysis of the present knowledge on leptin have prompted the author to undertake research aimed to determine the frequency of leptin combined genotypes (C3100T/Sau3AI), and to establish possible association between the genotypes and some milk performance traits in Black-and-White cows during 305-d lactation I, II, and III.

The results may prove useful and applicable as a criterion of early selection aimed at improving the milk performance of cattle.

\section{Material and methods}

The study covered 860 Black-and-White cows with different share of HolsteinFriesian (hf) genes (averaged 68\%), kept at 5 farms in Western Pomerania. Analysis included the cows with at least the first lactation completed. From among the group, only 624 animals completed the first and second lactations, and 390 completed the first, second, and third lactations. Animals were born in years 1990-1998 and coming from 178 sires.

The blood from an external jugular vein was collected into tubes with $\mathrm{K}_{3}$ EDTA. DNA was isolated with MasterPure kit (Epicentre Technologies), according to the producer's instructions.

Two polymorphisms in the leptin gene were analysed. The first polymorphic site analysed is situated in the third exon; it is the C3100T transition (Genbank accession number U50365) recognised by $\mathrm{HphI}$ and results in A80V in the encoded polypeptide (A59V change in the secreted protein). The other polymorphism is situated within the 
second intron sequence; it is the C2059T transition (Genbank accession number U50365) and an additional rare polymorphic site, both recognised by Sau3AI. The exact location of the last one is unknown, therefore the intronic polymorphism will be named LEP-Sau3AI and the respective alleles as A and B, and generated by an additional polymorphism as C.

Genotypes analyses were performed using the PCR-RFLP method. Amplification of the desired leptin gene fragments was performed with appropriate primer pairs on the following nucleotide sequences: 5'-GGGAAGGGCAGAAAGATAG-3' and 5'TGGCAGACTGTTG AGGATC-3', a 331 base pair-long fragment (C3100T polymorphism) (HAEGEMAN et al., 2000); 5'-GTCACCAGGATCAATGACAT-3' and 5'-AGCCCAGGAATGAAGTCCAA-3', a 1820 base pair-long fragment (Sau3AI polymorphism) (POMP et al., 1997).

The PCR was performed in a total volume of $20 \mu$ containing containing 50-100 ng DNA, $20 \mathrm{mM}$ Taq polymerase buffer, $2 \mathrm{mM} \mathrm{MgCl}_{2}$, 10 pmol each primer, $200 \mathrm{mM}$ each dNTP, and 0,5 U Taq DNA polymerase. The PCR proceeded in T3 and TGradient (Biometra ${ }^{\circledR}$ ) and Mastercycler Gradient (Eppendorf ${ }^{\circledR}$ ) thermocyclers in the appropriate thermal conditions.

At the next step, the PCR products were digested with appropriate restriction enzymes: the 331 base pair fragment with HphI and the 1820 base pair one with Sau3AI.

The restriction fragments obtained were separated on $2 \%$ agarose gels with ethidium bromide $(0.5 \mu \mathrm{g} / \mathrm{ml})$ in the presence of appropriate DNA standards, and described using the Vilber Lourmat software for photodocumentation of electrophoretic separation and image storage.

The next stage involved analysis of associations between leptin combined genotypes and the following milk performance traits: milk yield (kg), maximum daily milk yield $(\mathrm{kg})$, protein and fat yield (kg), protein and fat content in milk (\%). Data on milk performance of the cows were retrieved from records kept at farms as a part of cattle milk performance assessment programme.

Statistical analysis of milk performance traits in relation to leptin combined genotypes was carried using the GLM procedure - model II (SAS ${ }^{\circledR}$ package - 1990). Differences between mean values of the traits were tested with Duncan's multiple range test. The following linear model was applied to all the traits analysed in the first lactation:

where:

$$
Y_{i j k l m n}=\mu+S_{i}+R_{j}+O_{k}+(S R O)_{i j k}+G_{l}+h f_{m}+e_{i j k l m n}
$$

$$
\begin{array}{ll}
Y_{i j k l m n} & \text { - observed value; } \\
\mu & \text { - trait mean; } \\
S_{i} & \text { - herd effect }(i=1 \ldots 5) ; \\
R_{j} & \text { - year of birth effect }(j=1 \ldots 9) ; \\
O_{k} & \text { - sire effect }(k=1 \ldots 178) ; \\
(S R O)_{i j k} & \text { - herd x year of birth x sire interaction effect; } \\
G_{l} & \text { - combined genotype effect }(l=1 \ldots 10) ; \\
h f_{m} & \text { - hf gene effect }(m=1 \ldots 48) ; \\
e_{i j k l m n} & \text { - error. }
\end{array}
$$

The analogical linear models were applied to the second and the third lactations.

\section{Results}

The 331 base pair PCR product digested with HphI revealed non-cutting fragment of 331 bp (allele C) and cutting fragments of 311 and 20 bp (allele T). It resulted in three 
different genotypes: CC, CT and TT. The 1820 bp one digested with Sau3AI revealed fragments of 730, 690, 400 bp (allele A), 730, 690, 310, 90 bp (allele B) and 730, $\sim 470,400, \sim 220$ bp (allele C); it resulted in six genotypes: AA, AB, BB, AC, BC, CC. Analysis of the combined genotype C3100T/Sau3AI frequencies showed the CC/AA genotype to be most frequent $(0.315)$ in the Black-and-White cow herd. The CT/AA and $\mathrm{CC} / \mathrm{AB}$ genotypes were found to occur less frequently $(0.272$ and 0.142 , respectively). The frequencies of the remaining combined genotypes did not exceed 0.100 (Table 1). Allele frequencies of each polymorphism alone were estimated as follows: C $-0.760, \mathrm{~T}-0.240$ for LEP-C3100T and A - 0.805, B - 0.114, C -0.081 for LEP-Sau3AI (Table 2).

Table 1

Frequency of LEP-C3100T/Sau3AI genotypes of Polish Black-and-White cows (Frequenzen der Genotypen LEP-C3100T/Sau3AI bei Polnischen Schwarzbunten Kühen)

\begin{tabular}{ccccccccccccc}
\hline \multirow{2}{*}{ Herd } & \multirow{n}{*}{$\mathrm{n}$} & \multicolumn{10}{c}{ Combined genotype C3100T/Sau3AI } \\
\cline { 3 - 13 } & & CC/AA & CC/AB & CC/BB & CC/AC & CC/BC & CC/CC & CT/AA & CT/AB & CT/AC & TT/AA & TT/AB \\
\hline I & 141 & 0.241 & 0.184 & 0.014 & 0.065 & 0.007 & 0.014 & 0.326 & 0.035 & 0.050 & 0.064 & 0.000 \\
II & 123 & 0.422 & 0.130 & 0.008 & 0.106 & 0.000 & 0.008 & 0.203 & 0.033 & 0.049 & 0.041 & 0.000 \\
III & 278 & 0.288 & 0.140 & 0.004 & 0.097 & 0.018 & 0.004 & 0.288 & 0.050 & 0.050 & 0.061 & 0.000 \\
IV & 117 & 0.308 & 0.154 & 0.043 & 0.068 & 0.009 & 0.017 & 0.265 & 0.043 & 0.068 & 0.017 & 0.008 \\
V & 201 & 0.343 & 0.114 & 0.015 & 0.089 & 0.015 & 0.000 & 0.259 & 0.060 & 0.030 & 0.070 & 0.005 \\
\hline Total & 860 & 0.315 & 0.142 & 0.014 & 0.087 & 0.012 & 0.007 & 0.272 & 0.046 & 0.048 & 0.055 & 0.002 \\
\hline
\end{tabular}

Table 2

Frequency of LEP-C3100T and LEP-Sau3AI alleles of Polish Black-and-White cows (Frequenzen der Allele LEP-C3100T and LEP-Sau3AI bei Polnischen Schwarzbunten Kühen)

\begin{tabular}{ccccccc}
\hline \multirow{2}{*}{ Herd } & \multirow{2}{*}{$\mathrm{n}$} & \multicolumn{2}{c}{ LEP-C3100T alleles } & \multicolumn{3}{c}{ LEP-Sau3AI alleles } \\
\cline { 3 - 7 } & & $\mathrm{C}$ & $\mathrm{T}$ & $\mathrm{A}$ & $\mathrm{B}$ & $\mathrm{C}$ \\
\hline $\mathrm{I}$ & 141 & 0.730 & 0.270 & 0.798 & 0.128 & 0.074 \\
II & 123 & 0.817 & 0.183 & 0.825 & 0.090 & 0.085 \\
III & 278 & 0.745 & 0.255 & 0.806 & 0.108 & 0.086 \\
IV & 117 & 0.786 & 0.214 & 0.765 & 0.145 & 0.090 \\
V & 201 & 0.751 & 0.249 & 0.823 & 0.109 & 0,068 \\
\hline Total & 860 & 0.760 & 0.240 & 0.805 & 0.114 & 0.081 \\
\hline
\end{tabular}

Table 3 illustrates associations between the C3100T/Sau3AI genotypes and the milk performance traits of the Black-and-White cows under study. Due to the low number of the TT/AB genotype cows (2 individuals), they were not included in the analysis involving all the lactations, while the CC/CC cows were disregarded in the statistical analysis applied to lactation III (1 individual). Therefore, 585, 622 and 387 cows were analysed, respectively in the first, second and third lactations.

The analysis of data showed the CC/BB genotype individuals to be characterised by the highest milk yield, the yield in lactation I, II, and III amounting to 5789, 7577, and $8027 \mathrm{~kg}$, respectively. Significant $(\mathrm{P} \leq 0.01)$ differences in milk yield between cows of different combined genotypes were detected in lactation II and III. The largest differences in milk yield, $2159 \mathrm{~kg}$ in lactation II and $3563 \mathrm{~kg}$ in lactation III, were found between individuals of $\mathrm{CC} / \mathrm{BB}$ and $\mathrm{CC} / \mathrm{BC}$ genotypes.

The maximum daily milk yield was the highest in the TT/AB genotype individuals in lactation I (30.1 kg), the CC/CC genotype individuals in lactation II (34.8 kg), and CC/BB genotype individuals in lactation III $(35.3 \mathrm{~kg})$. Significant differences in the maximum daily milk yield between cows of different combined genotypes were found in lactation II and III. In lactation II, the largest difference (8.9 kg) was found for the 
TT/CC and CC/BC cows. In lactation III, the largest difference (5.5 kg) was observed between the maximum daily milk yield of the CC/BB and CT/AC cows.

Table 3

Means and standard deviations of milk performance traits in cows with different LEP-C3100T/Sau3AI genotypes (Mittelwerte und Standardabweichungen der Milchleistungsmerkmale bei Kühen mit verschiedenen LEP-C3100T/Sau3AI-Genotypen) (L - lactation, $\mathrm{n}$ - number of observations among the group)

\begin{tabular}{|c|c|c|c|c|c|c|c|c|}
\hline \multirow{2}{*}{$\mathrm{L}$} & \multirow{2}{*}{$\begin{array}{c}\text { C3100T/ } \\
\text { Sau3AI }\end{array}$} & \multirow[b]{2}{*}{$\mathrm{n}$} & \multirow[b]{2}{*}{ Milk yield (kg) } & \multirow{2}{*}{$\begin{array}{l}\text { Maximum } \\
\text { daily milk yield } \\
\text { (kg) }\end{array}$} & \multicolumn{2}{|c|}{ Milk protein } & \multicolumn{2}{|l|}{ Milk fat } \\
\hline & & & & & $\mathrm{kg}$ & $\%$ & $\mathrm{~kg}$ & $\%$ \\
\hline \multirow{20}{*}{ I } & CC/AA & 271 & $\begin{array}{l}5362 \\
(1515)\end{array}$ & $\begin{array}{l}24.4 \\
(7.0)\end{array}$ & $\begin{array}{l}170.7 \\
(51.3)\end{array}$ & $\begin{array}{l}3.18 \\
(0.19)\end{array}$ & $\begin{array}{l}224.6 \\
(70.3)\end{array}$ & $\begin{array}{l}4.17 \\
(0.46)\end{array}$ \\
\hline & $\mathrm{CC} / \mathrm{AB}$ & 122 & 5116 & 23.9 & 161.3 & 3.16 & 212.3 & 4.17 \\
\hline & & & $(1270)$ & $(6.1)$ & $(42.2)$ & $(0.18)$ & (55.3) & $(0.43)$ \\
\hline & $\mathrm{CC} / \mathrm{BB}$ & 12 & 5789 & 24.3 & 189.5 & 3.21 & 241.5 & 4.13 \\
\hline & & & (1393) & (5.3) & (51.1) & (0.19) & $(59.2)$ & $(0.35)$ \\
\hline & $\mathrm{CC} / \mathrm{AC}$ & 75 & 5473 & 25.3 & 174.4 & 3.19 & 226.7 & 4.15 \\
\hline & & & (1374) & $(6.4)$ & (46.3) & $(0.20)$ & $(60.7)$ & $(0.40)$ \\
\hline & $\mathrm{CC} / \mathrm{BC}$ & 10 & 5145 & 22.2 & 158.5 & 3.06 & 205.7 & 4.03 \\
\hline & & & (1209) & $(4.8)$ & (43.4) & $(0.12)$ & $(49.0)$ & $(0.54)$ \\
\hline & $\mathrm{CC} / \mathrm{CC}$ & 6 & 5391 & 28.3 & 177.0 & 3.26 & 228.3 & 4.18 \\
\hline & & & (2229) & $(8.2)$ & (76.3) & $(0.10)$ & (103.2) & $(0.44)$ \\
\hline & CT/AA & 234 & 5085 & 23.3 & 160.2 & 3.14 & 208.3 & 4.11 \\
\hline & & & (1378) & $(6.0)$ & (45.9) & $(0.21)$ & $(57.2)$ & $(0.44)$ \\
\hline & $\mathrm{CT} / \mathrm{AB}$ & 40 & 5050 & 22.3 & 158.7 & 3.12 & 209.0 & 4.12 \\
\hline & & & (1249) & $(5.2)$ & $(43.0)$ & (0.19) & (58.8) & $(0.38)$ \\
\hline & CT/AC & 41 & 5505 & 25.0 & 173.1 & 3.13 & 228.7 & 4.12 \\
\hline & & & (1393) & $(6.4)$ & (47.5) & $(0.20)$ & (72.6) & $(0.47)$ \\
\hline & TT/AA & 47 & 5067 & 23.5 & 159.5 & 3.14 & 206.0 & 4.06 \\
\hline & & & (1280) & $(5.6)$ & (41.2) & $(0.16)$ & (58.8) & $(0.40)$ \\
\hline & Total & 858 & 5243 & 24.0 & 166.0 & 3.16 & 217.1 & 4.14 \\
\hline \multirow{21}{*}{ II } & CC/AA & 172 & $5742^{\mathrm{A}}$ & $27.7^{\mathrm{AG}}$ & $187.6^{\mathrm{A}}$ & 3.25 & $249.9^{A}$ & 4.34 \\
\hline & & & (1436) & $(6.7)$ & $(50.7)$ & $(0.23)$ & (74.1) & $(0.53)$ \\
\hline & $\mathrm{CC} / \mathrm{AB}$ & 87 & $5513^{\mathrm{B}}$ & $26.8^{\mathrm{BH}}$ & $179.4^{\mathrm{B}}$ & 3.22 & $233.7^{\mathrm{B}}$ & 4.23 \\
\hline & & & $(1388)$ & $(6.0)$ & $(46.6)$ & $(0.25)$ & (63.3) & $(0.50)$ \\
\hline & $\mathrm{CC} / \mathrm{BB}$ & 8 & $7577^{\text {ABCDEFGHI }}$ & $34.1^{\mathrm{ABCDEF}}$ & 244.2 $2^{\mathrm{ABCDEFGHI}}$ & 3.21 & 319.6 ABCDEFGHI & 4.23 \\
\hline & & & $(1414)$ & $(6.2)$ & $(51.9)$ & $(0.17)$ & $(60.6)$ & $(0.37)$ \\
\hline & $\mathrm{CC} / \mathrm{AC}$ & 56 & $6015^{\mathrm{C}}$ & $28.8^{\mathrm{I}}$ & $194.5^{\mathrm{C}}$ & 3.24 & $250.3^{C}$ & 4.17 \\
\hline & & & (1657) & (6.9) & (54.8) & $(0.23)$ & (79.1) & $(0.61)$ \\
\hline & $\mathrm{CC} / \mathrm{BC}$ & 8 & $5418^{\mathrm{D}}$ & $25.9^{\mathrm{CJ}}$ & $171.6^{\mathrm{D}}$ & 3.17 & $212.0^{\mathrm{D}}$ & 3.92 \\
\hline & & & (1357) & (6.5) & $(44.4)$ & (0.09) & (61.9) & $(0.54)$ \\
\hline & $\mathrm{CC} / \mathrm{CC}$ & 5 & $6168^{\mathrm{E}}$ & $34.8^{\text {GHILKLM }}$ & $206.2^{\mathrm{E}}$ & 3.33 & $250.8^{\mathrm{E}}$ & 3.99 \\
\hline & & & (1324) & $(9.1)$ & $(48.7)$ & $(0.14)$ & (89.5) & $(0.76)$ \\
\hline & CT/AA & 181 & $5579^{\mathrm{F}}$ & $27.3^{\mathrm{DK}}$ & $177.5^{\mathrm{F}}$ & 3.20 & $234.0^{\mathrm{F}}$ & 4.17 \\
\hline & & & (1295) & (6.3) & $(46.1)$ & $(0.21)$ & (66.5) & $(0.58)$ \\
\hline & CT/AB & 37 & $5709^{\mathrm{G}}$ & $27.5^{\mathrm{EL}}$ & $180.5^{\mathrm{G}}$ & 3.16 & $236.1^{\mathrm{G}}$ & 4.12 \\
\hline & & & (1474) & $(7.0)$ & $(49.7)$ & $(0.23)$ & $(72.2)$ & $(0.53)$ \\
\hline & $\mathrm{CT} / \mathrm{AC}$ & 29 & $6179^{\mathrm{H}}$ & 30.5 & $198.6^{\mathrm{H}}$ & 3.20 & $255.4^{\mathrm{H}}$ & 4.06 \\
\hline & & & (1435) & $(7.7)$ & $(50.0)$ & (0.19) & $(92.4)$ & $(0.60)$ \\
\hline & TT/AA & 39 & $5515^{1}$ & $27.6^{\mathrm{FM}}$ & $179.7^{1}$ & 3.22 & $226.3^{I}$ & 4.00 \\
\hline & & & (1347) & $(5.5)$ & (46.3) & $(0.19)$ & $(61.1)$ & $(0.46)$ \\
\hline & Total & 622 & 5715 & 27.8 & 184.4 & 3.22 & 241.4 & 4.20 \\
\hline \multirow{19}{*}{ III } & CC/AA & 101 & $6203^{A}$ & $29.9^{\mathrm{A}}$ & $202.4^{\mathrm{A}}$ & 3.26 & 271.0 & 4.34 \\
\hline & & & (1563) & (6.9) & $(52.7)$ & $(0.20)$ & (76.3) & $(0.55)$ \\
\hline & $\mathrm{CC} / \mathrm{AB}$ & 58 & $5979^{B}$ & $29.3^{\mathrm{B}}$ & $195.5^{\mathrm{B}}$ & 3.19 & 252.3 & 4.10 \\
\hline & & & $(1542)$ & $(7.0)$ & (48.9) & $(0.17)$ & (75.1) & $(0.49)$ \\
\hline & $\mathrm{CC} / \mathrm{BB}$ & 5 & $8027^{\mathrm{ABCDEFGH}}$ & $35.3^{\mathrm{ABCDEF}}$ & $257.2^{\mathrm{ABCDEFGH}}$ & 3.21 & $333.8^{\mathrm{ABCD}}$ & 4.12 \\
\hline & & & $(1314)$ & (4.1) & $(43.4)$ & (0.19) & (87.9) & $(0.61)$ \\
\hline & $\mathrm{CC} / \mathrm{AC}$ & 33 & $5928^{\mathrm{C}}$ & 31.1 & $187.6^{\mathrm{C}}$ & 3.15 & $242.5^{\mathrm{A}}$ & 4.04 \\
\hline & & & (1551) & (4.8) & (52.1) & (0.17) & (79.5) & $(0.52)$ \\
\hline & $\mathrm{CC} / \mathrm{BC}$ & 6 & $4464^{\mathrm{D}}$ & 31.7 & $183.0^{\mathrm{D}}$ & 2.99 & 252.8 & 4.09 \\
\hline & & & (1739) & (7.7) & (77.1) & (0.19) & (119.2) & $(0.87)$ \\
\hline & CT/AA & 114 & $5881^{\mathrm{E}}$ & $29.0^{\mathrm{C}}$ & $188.4^{\mathrm{E}}$ & 3.17 & $246.9^{\mathrm{B}}$ & 4.17 \\
\hline & & & (1415) & (5.6) & (48.3) & $(0.20)$ & (72.4) & (0.61) \\
\hline & $\mathrm{CT} / \mathrm{AB}$ & 27 & $5903^{F}$ & $29.3^{D}$ & $182.4^{\mathrm{F}}$ & 3.10 & $236.0^{\mathrm{C}}$ & 4.00 \\
\hline & & & (1691) & $(6.2)$ & (50.8) & $(0.16)$ & (74.9) & $(0.57)$ \\
\hline & CT/AC & 17 & $6237^{G}$ & $28.9^{\mathrm{E}}$ & $195.1^{\mathrm{G}}$ & 3.11 & 258.6 & 4.07 \\
\hline & & & (1626) & (5.4) & (53.1) & $(0.16)$ & (91.5) & $(0.58)$ \\
\hline & TT/AA & 26 & $5778^{\mathrm{H}}$ & $30.1^{F}$ & $186.6^{\mathrm{H}}$ & 3.16 & $230.6^{\mathrm{D}}$ & 3.97 \\
\hline & & & (1712) & $(6.0)$ & (55.9) & $(0.19)$ & $(71.2)$ & $(0.32)$ \\
\hline & Total & 387 & 6003 & 29.7 & 193.6 & 3.18 & 253.7 & 4.16 \\
\hline
\end{tabular}

$\mathrm{A}, \mathrm{B}, \mathrm{C}, \mathrm{D}, \mathrm{E}, \mathrm{E}, \mathrm{G}, \mathrm{H}, \mathrm{I}$ - within columns means bearing the same superscript differ significantly at $\mathrm{P} \leq 0.01$ 
In terms of protein yield, the highest mean value was found in milk from the CC/BB genotype cows in each lactation (189.5; 244.2; and $257.2 \mathrm{~kg}$, respectively). Significant $(\mathrm{P} \leq 0.01)$ differences between different genotypes were detected in lactation II and III. In lactation II, the largest difference in protein yield $(72.6 \mathrm{~kg})$ was observed between the $\mathrm{CC} / \mathrm{BB}$ and $\mathrm{CC} / \mathrm{BC}$ cows. In lactation III, the largest difference $(74.8 \mathrm{~kg})$ was that between the $\mathrm{CC} / \mathrm{BB}$ and $\mathrm{CT} / \mathrm{AB}$ genotypes.

The highest per cent milk protein contents were recorded in the CC/CC cows in lactation I and II as well as in the CC/AA genotype in lactation III. However, the differences in the per cent milk protein content obtained from different combined genotypes were statistically non-significant.

The fat yield data showed a tendency similar to that revealed for the protein yield. The highest mean fat yield in the three subsequent lactations (241.5, 319.6, and $333.8 \mathrm{~kg}$, respectively) were found for the $\mathrm{CC} / \mathrm{BB}$ cows. Differences in fat yield between those and all the other cows were significant $(\mathrm{P} \leq 0.01)$ in lactation II and III. In lactation II, the largest difference $(107.6 \mathrm{~kg})$ was observed between the $\mathrm{CC} / \mathrm{BB}$ and $\mathrm{CC} / \mathrm{BC}$ cows. In lactation III, the largest difference of $103.2 \mathrm{~kg}$ was recorded between the $\mathrm{CC} / \mathrm{BB}$ and TT/AA cows.

The highest milk per cent fat content was found for the CC/AA cows in lactation I and II as well as for the CC/CC cows in lactation III. However, the differences in this trait between different genotypes were statistically non-significant.

\section{Discussion}

Analysis of the LEP-C3100T/Sau3AI genotype frequencies showed the CC/AA genotype to be most frequent (0.315) in the Black-and-White cow herd. The LEPC3100T - C and LEP-Sau3AI - A alleles appeared with frequencies 0.760 and 0.805, respectively, which was comparable to reference data (HAEGEMAN et al., 2000; LIEFERS et al., 2002; ZWIERZCHOWSKI et al., 2002).

The results of the experiment showed the association between the leptin combined genotype and milk performances in Polish Black-and-White cows. The CC/BB genotype individuals are characterised by the highest yields of milk, protein and fat. Statistically significant $(\mathrm{P} \leq 0.01)$ relationship between the LEP-C3100T and LEPSau3AI polymorphism alone and milk, protein and fat yield were also observed. These traits were significantly higher in the LEP-C3100T - CC and LEP-Sau3AI - BB genotypes (KULIG, 2005).

Referring to the above performance traits, the leptin C3100T - CC and Sau3AI - BB genotypes superiority, as compared to the others genotypes, was confirmed in a combined genotype analysis.

There is no literature data on associations between leptin combined genotypes and milk performance traits in cattle, but associations between the LEP-Sau3AI polymorphism and these traits were founded in Holstein-Friesian. The AB genotype cows showed a significantly higher daily milk, protein, and lactose yields, compared to the AA genotype cows (LIEFERS et al., 2002). The study involved only three genotypes: $\mathrm{AA}, \mathrm{AB}$, and $\mathrm{BB}$. Contradictory results of the our study (the $\mathrm{BB}$ genotype cows to be superior) compared to the above may be explained by breed/population differences, the small number of the BB genotype cows or the factors influenced milk production traits. Another study (ZWIERZCHOWSKI et al., 2002) found an association between the LEP-Sau3AI genotypes and per cent contents of certain milk 
components in the Polish Black-and-White cows. The AC genotype individuals showed a higher sum of fat, protein, lactose, and minerals per cent content of as well as a higher fat and protein contents, compared to the AB genotype cows. The study did not involve the CC cows (absent in the herd); neither did it include the $\mathrm{BB}$ and $\mathrm{BC}$ genotypes due to the low number of cows in both.

The alanine/valine change is situated in the conserved region of the $\beta$-helix and both amino acids are non-polar. Therefore, A80V change have not probably influence the protein conformation. This polymorphism and the intronic one (Sau3AI) might be molecular markers for yields of milk and its components (protein and fat).

Worth mentioning is the tremendous role of leptin in metabolism. Leptin has been suggested to inform the hypothalamus on energy reserves sufficient to support sexual maturation and reproduction, which can ensure successful gestation and lactation (CASABIELL et al., 2001). In addition, the mammary gland is known to be a site of leptin production, the leptin itself being detectable in milk (BONNET et al., 2002). Moreover, a significant positive correlation between leptin level and fat content was found in edible commercial milk (LAGE et al., 2002).

It is worth adding that leptin gene expression and leptin release are controlled by concerted action of numerous hormones (estradiol, prolactin, glucocorticoids, and insulin), which are also involved in the differentiation and functioning of the mammary gland and lactation (BRANN et al., 1999; CONSIDINE, 1997; SALADIN et al., 1995).

Research on associations between leptin combined genotypes and milk performance traits in cattle merits continuation as the relevant knowledge is very scant. Continuing these investigations will permit verification of the presented results before using them in dairy selection programmes. It would be also desirable to expand the research to cover other leptin combined genotypes.

\section{References}

BADO, A.; LEVASSEUR, S.; ATTOUB, S.; KERMORGANT, S.; LAIGNEAU, J.P.; BORTOLUZZI, M.N.; MOIZO, L.; LEHY, T.; GUERRE-MILLO, M.; LE MARCHAND-BRUSTEL, Y.; LEWIN, M.J.:

The stomach is a source of leptin. Nature 394 (1998), 790-793

BARASH, I.A.; CHEUNG, C.C.; WEIGLE, D.S.; REN, H.; KABIGTING, E.B.; KUIJPER, J.L.; CLIFTON, D.K.; STEINER, R.A.:

Leptin is a metabolic signal to the reproductive system. Endocrinology 137 (1996), 3144-3147

BONNET, M.; DELAVAUD, C.; LAUD, K.; GOURDOU, I.; LEROUX, C.; DJIANE, J.; CHILLIARD, Y.:

Mammary leptin synthesis, milk leptin and their putative physiological roles. Reproduction, Nutrition and Development 42 (2002), 399-413

BRANN, D.W.; DE SEVILLA, L.; ZAMORANO, P.L.; MAHESH, V.B.:

Regulation of leptin gene expression and secretion by steroid hormones. Steroids 64 (1999), 659-663

BRUNNER, L.; CUMIN, N.F.; CHIESI, M.; BAUM, H.-P.; WHITEBREAD, S.; STRIECKER-KRONGRAD, A.; LEVENS, N.:

Leptin is a physiologicaly important regulator of food intake. International Journal of Obesity 21 (1997), 1152-1160

BUCHANAN, F.C.; VAN KESSEL, A.G.; WALDNER, C.; CHRISTENSEN, D.A.; LAARVELD, B.; SCHMUTZ, S.M.:

Hot Topic: An association between a leptin single nucleotide polymorphism and milk and protein yield. Journal of Dairy Science 86 (2003), 3164-3166

CASABIELL, X.; PIÑEIRO, V.; VEGA, F.; DE LA CRUZ, L.F.; DIÉGUEZ, C.; CASANUEVA, F.F.: Leptin, reproduction and sex steroids. Pituitary 4 (2001), 93-99

CONSIDINE, R.V.:

Weight regulation, leptin and growth hormone. Hormone Research 48 (Suppl. 5) (1997), 116-121

DELAVAUD, C.; FERLAY, A.; FAULCONNIER, Y.; BOCQUIER, F.; KANN, G.; CHILLIARD, Y.: 
Plasma leptin concentration in adult cattle: Effects of breed, adiposity, feeding level, and meal intake. Journal of Animal Science 80 (2002), 1317-1328

GONG, D.-W.; BI, S.; PRATLEY, R.E.; WEINTRAUB, B.D.:

Genomic structure and promoter analysis of the human obese gene. The Journal of Biological Chemistry 271 (1996), 3971-3974

GRAML, R.; PIRCHNER, F.:

Effect of milk protein loci on content of their proteins. Arch. Tierz., Dummerstorf 46 (2003), 331-340

HAEGEMAN, A.; VAN ZEVEREN, A.; PEELMAN, L.J.:

New mutation in exon 2 of the bovine leptin gene. Animal Genetics 31 (2000), 79

HALAAS, J.L.; GAJIWALA, K.S.; MAFFEI, M.; COHEN, S.L.; CHAIT, B.T.; RABINOWITZ, D.; LALLONE, R.L.; BURLEY, S.K.; FRIEDMAN, J.M.:

Weight-reducing effects of the plasma protein encoded by the obese gene. Science 269 (1995), 543-546

HOUSEKNECHT, K.L.; PORTOCARRERO, C.P.:

Leptin and its receptors: regulators of whole-body energy homeostasis. Domestic Animal Endocrinology 15 (1998), 457-475

JI, S.; WILLIS, G.M.; SCOTT, R.R.; SPURLOCK, M.E.:

KULIG, H.

Partial cloning and expression of the bovine leptin gene. Animal Biotechnology 9 (1998), 1-14

Associations between leptin gene polymorphism and same milk performance traits of cattle. J. of Animal and Feed Sciences 14 (2005), 235-243

LAGE, M.; BALDELLI, R.; CAMIÑA, J.P.; RODRIGUEZ-GARCIA, J.; PEÑALVA, A.; DIEGUEZ, C.; CASANUEVA, F.F.:

Presence of bovine leptin in edible commercial milk and infant formula. Journal of Endocrinological Investigation 25 (2002), 670-674

LIEFERS, S.C.; TE PAS, M.F.; VEERKAMP, R.F.; VAN DER LENDE, T.:

Associations between leptin gene polymorphisms and production, live weight, energy balance, feed intake, and fertility in Holstein heifers. Journal of Dairy Science 85 (2002), 1633-1638

LINDERSSON, M.; ANDERSSON-EKLUND, L.; DE KONING, D.-J.; LUNDÉN, A.; MÄKI-TANILA, A.; ANDERSSON, L.:

Mapping of serum amylase-1 and quantitative trait loci for milk production traits to chromosome 4. Journal of Dairy Science 81 (1998), 1454-1461

LORD, G.M.; MATARESE, G.; HOWARD, J.K.; BAKER, R.J.; BLOOM, S.R.; LECHLER, R.I.:

Leptin modulates the T-cell immune response and reserves starvation-induced immunosuppression. Nature 394 (1998), 897-901

POMP, D.; ZOU, T.; CLUTTER, A.C.; BARENDSE, W.:

Rapid communication: Mapping of leptin to bovine chromosome 4 by linkage analysis of a pcr-based polymorphism. Journal of Animal Science 75 (1997), 1427

SALADIN, R.; DE VOS, P.; GUERRE-MILLO, M.; LETURQUE, A.; GIRARD, J.; STAELS, B.; AUWERX, J.:

Transient increase in obese gene expression after food intake or insulin administration. Nature 377 (1995), 527-529

SAS/STAT User's Guide, Version 6,4 ${ }^{\text {th }}$ ed., SAS Institute Inc., Cary, NC, USA, 1990

STONE, R.T.; KAPPES, S.M.; BEATTIE, C.W.: The bovine homolog of the obese gene maps to chromosome 4. Mammalian Genome 7 (1996), 399-400

TSUCHIYA, T.; NAGAO, Y.; OZAWA, A.; MATSUMOTO, M.; SUGAHARA, K.; KUBO, T.; KATO, H.: Decrease of the obese gene expression in bovine subcutaneous adipose tissue by fasting. Bioscience Biotechnology and Biochemistry 62 (1998), 2068-2069

XIE, C.; ALBRECHT, E.; WEGNER, J.; BROCKMANN, G.A.; KAZALA, C.; WESELAKE, R,J.; ENDER, K.: Leptin, a palatability molecule? - A review. Arch. Tierz., Dummerstorf 42 (1999), 191-199

ZHANG, Y.; PROENCA, R.; MAFFEI, M.; BARONE, M.; LEOPOLD, L.; FRIEDMAN, J.M.: Positional cloning of the mouse obese gene and its human homologue. Nature 372 (1994), 425-432

ZWIERZCHOWSKI, L.; KRZYŻEWSKI, J.; STRZAŁKOWSKA, N.; SIADKOWSKA, E.; RYNIEWICZ, Z.: Effects of polymorphism of growth hormone (GH), Pit-1, and leptin (LEP) genes, cow's age, lactation stage and somatic cell count on milk yield and composition of Polish Black-and-White cows. Animal Science Papers and Reports 20 (2002), 213-227 